\title{
Preparation of Diuridine and Dicytidine Pentaphosphates
}

\author{
Yue-Hai YOU1, a, Shan-Shan GONG ${ }^{1, b}$, Qi SUN ${ }^{1, c, ~ * ~}$ \\ ${ }^{1}$ Jiangxi Key Laboratory of Organic Chemistry, Jiangxi Science and Technology \\ Normal University 605 Fenglin Avenue, Nanchang, Jiangxi 330013, PR China \\ aemail: 136504960@qq.com, bemail: gongshanshan33@gmail.com, cemail: \\ sunqi96@tsinghua.org.cn
}

${ }^{*}$ Corresponding author

Keywords: Phosphoropiperidate, Dinucleoside pentaphosphates, Cytidine, Uridine, 4,5-dicyanoimidazole.

\begin{abstract}
Two symmetrical dinucleoside pentaphosphates, $\mathrm{Up}_{5} \mathrm{U}$ and $\mathrm{Cp}_{5} \mathrm{C}$, were synthesized via the activation of the $\mathrm{P}(\mathrm{V})-\mathrm{N}$ bond. The key nucleoside phosphoropiperidates intermediate were obtained by a redox condensation method. The reaction of the phosphoropiperidate with uridine and cytidine tetraphosphate in the presence of 4, 5-dicyanoimidazole (DCI) afforded the desired dinucleoside pentaphosphates in moderate isolated yields.
\end{abstract}

\section{Introduction}

Dinucleoside polyphosphates, or dinucleotides $\left(\mathrm{Np}_{n} \mathrm{~N}^{\prime} \mathrm{N}, \mathrm{N}^{\prime}=\mathrm{A}, \mathrm{U}, \mathrm{G}, \mathrm{C} ; n=2-7\right)$ are naturally occurring compounds [1]. They consist of a polyphosphate chain linked to two nucleosides at the 5'-positions on both ends. Many important functions have been elucidated for $A p_{n} A s, A p_{n} G$ s and $G_{p}$ Gs in various biological processes, such as platelet disaggregation, neurotransmission, modulation of vascular tone, and cell signaling [2-5]. They have also been shown to act as substrates for a variety of DNA polymerases and function as inhibitors of kinases, endoribonuclease, IMP dehydrogenase, and adenylosuccinate synthetase. In addition, the $\mathrm{Ap}_{4} \mathrm{~A}$ may be used as primers for DNA synthesis by DNA polymerase or for RNA polymerase, and the $A p_{5} \mathrm{~A}-\mathrm{Zn}^{2+}$ complex have been used to reveal preferred pathways that create the configuration capable of proficient chemistry in the catalysis of adenylate kinase [6-10]. Due to the chemical and metabolic stability of dinucleotides, they are attractive as therapeutic agents. Several $\mathrm{Np}_{n} \mathrm{~N}^{\prime}$ analogues have been administered in human clinical trials [11-13]. For instance, $\mathrm{Ap}_{4} \mathrm{~A}$ has been tested for lowering blood pressure during anesthesia. Artificial dinucleoside polyphosphates $\mathrm{Up}_{4} \mathrm{U}$ and $\mathrm{Up}_{4} \mathrm{dC}$ have been developed for the treatment of dry eye disease and cystic fibrosis, respectively.

Currently, the method for the preparation of dinucleoside pentaphosphates is still very limited and facile synthesis of dinucleoside pentaphosphates remains a challenge for phosphorus chemists. The most commonly used method is the approach based on the synthesis of dinucleoside di-, tri-, and tetraphosphates. The direct coupling of nucleoside diphosphates (NDPs) and nucleoside triphosphates with excess condensing reagents such as carbonyldiimidazole (CDI) or dicyclohexylcarbodiimide (DCC) could only afforded the desired products in low yields [14-16]. Recently, dinucleoside pentaphosphates including $\mathrm{Ap}_{5} \mathrm{~A}, \mathrm{G} \mathrm{p}_{5} \mathrm{G}$, and $\mathrm{Ap}_{5} \mathrm{G}$ have been efficiently synthesized by coupling nucleoside 5'-tetraphosphate with nucleoside 5'-phosphoromorpholidates with 4,5-dicyanoimidazole activator. On the basis of this approach, we report in this paper the synthesis of dicytidine and diuridine pentaphosphates from nucleoside 
phosphoropiperidate and corresponding nucleoside tetraphosphates via the activation of $\mathrm{P}(\mathrm{V})-\mathrm{N}$ bond of the phosphoropiperidate precursors.

\section{Experimental}

All reactions were performed in anhydrous solvents under an atmosphere of dry argon. The triethylammonium salts of nucleoside 5'-phosphoropiperidates were synthesized according to the procedure described in a previous report [17]. Nucleoside 5'-tetraphosphates was prepared according to a known method. Ion exchange chromatography employed DEAE Sephadex A-25 exchanger. Preparative HPLC was equipped with a RP C18 column $(19 \mathrm{~mm} 250 \mathrm{~mm}, 10 \mu \mathrm{m})$. NMR spectra were obtained with a $400 \mathrm{MHz}$ instrument with chemical shifts reported in parts per million (ppm, $\delta$ ) and referenced to $\mathrm{D}_{2} \mathrm{O}$. IR spectra were recorded on a FT-IR spectrometer. Low-resolution mass spectra were obtained with an ion trap mass spectrometer and reported as $\mathrm{m} / \mathrm{z}$.

\section{$P^{1}, P^{5}$-Dicytidine-5', 5'-Pentaphosphate, Pentasodium Salt (5)}

To a solution of cytidine 5'-phosphoropiperidate (1) (49 $\mathrm{mg}, 0.1 \mathrm{mmol}$ ) in $\mathrm{N}$-methylpyrrolidone $(2 \mathrm{~mL})$ were added cytidine 5 '-tetraphosphate (3) (tetra-n-butylammonium salt, $61 \mathrm{mg}, 0.04 \mathrm{mmol}$ ) and DCI $(24 \mathrm{mg}, 0.2 \mathrm{mmol})$. The reaction was stirred at $20{ }^{\circ} \mathrm{C}$ for $20 \mathrm{~h}$. The white precipitation was collected by centrifuge. The crude product was dissolved in deionized $\mathrm{H}_{2} \mathrm{O}(0.5 \mathrm{~mL})$ and loaded on a DEAE Sephadex A-25 ion exchange column $(1.6 \mathrm{~cm} 25 \mathrm{~cm})$. Elution with $\mathrm{NH}_{4} \mathrm{HCO}_{3}$ buffer (linear gradient 0.5 to $0.9 \mathrm{~mol} / \mathrm{L}$ ), combination of appropriate fractions, and lyophilization afforded dinucleoside pentaphosphate in ammonium salt form. To remove the small amount of contaminated polyphosphate byproducts, the ammonium salt was further purified by a preparative RP HPLC [flow rate $=20 \mathrm{~mL} / \mathrm{min}$; linear gradient of $0-10 \% \mathrm{MeOH}$ in TEAB buffer $(10 \mathrm{mmol} / \mathrm{L}, \mathrm{pH} 8.0)$ over $15 \mathrm{~min}$; UV detection at $254 \mathrm{~nm}$ ]. Combination of appropriate fractions and lyophilization afforded dinucleoside pentaphosphate in triethylammonium salt form. Passage of the solution of the triethylammonium salt in deionized $\mathrm{H}_{2} \mathrm{O}$ through a bed of Dowex $50 \mathrm{~W}-\mathrm{X} 8$ ion exchange resin $\left(\mathrm{Na}^{+}\right.$form) and lyophilization afforded $\mathbf{5}(14 \mathrm{mg}, 35 \%)$ as pentasodium salt. ${ }^{1} \mathrm{H}$ NMR $\left(400 \mathrm{MHz}, \mathrm{D}_{2} \mathrm{O}\right): \delta 7.84(\mathrm{~d}, J=7.2 \mathrm{~Hz}, 2 \mathrm{H}), 6.11(\mathrm{~d}, J=7.2 \mathrm{~Hz}, 2 \mathrm{H})$, 5.96-5.91 (m, 2H), 4.34-4.26 (m, 4H), 4.25-4.22 (m, 4H), 4.18-4.15 (m, 2H) ppm; ${ }^{13} \mathrm{C}$ NMR (100 MHz, $\left.\mathrm{D}_{2} \mathrm{O}\right): \delta 166.1,157.7,141.2,96.5,88.3,82.6,75.4,69.3,65.8 \mathrm{ppm} ;{ }^{31} \mathrm{P}$ NMR (162 MHz, $\left.\mathrm{D}_{2} \mathrm{O}\right): \delta-11.5(\mathrm{~m}, 2 \mathrm{P}),-22.9(\mathrm{~m}, 3 \mathrm{P})$; IR (KBr): $v_{\max } 3697,3443,2920$, 2580, 2353, 1658, 1601, 1529, 1495, 1409, 1291, 1242, 1120, 1080, 948, 810, 600, 516 $\mathrm{cm}^{-1}$; LRMS (ESI-): $\mathrm{m} / z$ calcd for $\mathrm{C}_{18} \mathrm{H}_{29} \mathrm{~N}_{6} \mathrm{O}_{24} \mathrm{P}_{5}[\mathrm{M}-\mathrm{H}]^{-}$868.0; found 868.1.

\section{$P^{1}, P^{5}$-Diuridine-5', 5' -Pentaphosphate, Pentasodium Salt (6)}

To a solution of uridine 5'-phosphoropiperidate (2) (49 $\mathrm{mg}, 0.1 \mathrm{mmol}$ ) in $\mathrm{N}$-methylpyrrolidone $(2 \mathrm{~mL})$ were added uridine 5 '-tetraphosphate (4) (tetra- $n$-butylammonium salt, $61 \mathrm{mg}, 0.04 \mathrm{mmol}$ ) and DCI $(24 \mathrm{mg}, 0.2 \mathrm{mmol})$. The reaction was stirred at $20{ }^{\circ} \mathrm{C}$ for $18 \mathrm{~h}$. The white precipitation was collected by centrifuge. The crude product was dissolved in deionized $\mathrm{H}_{2} \mathrm{O}(0.5 \mathrm{~mL})$ and loaded on a DEAE Sephadex A-25 ion exchange column $(1.6 \mathrm{~cm} 25 \mathrm{~cm})$. Elution with $\mathrm{NH}_{4} \mathrm{HCO}_{3}$ buffer (linear gradient 0.5 to $0.9 \mathrm{~mol} / \mathrm{L}$ ), combination of appropriate fractions, and lyophilization afforded dinucleoside pentaphosphate in ammonium salt form. To remove the small amount of contaminated polyphosphate byproducts, the ammonium salt was further purified by a preparative RP HPLC [flow rate $=20 \mathrm{~mL} / \mathrm{min}$; linear gradient of $0-10 \% \mathrm{MeOH}$ in TEAB buffer (10 mmol/L, $\mathrm{pH} \mathrm{8.0)} \mathrm{over} 15 \mathrm{~min}$; UV 
detection at $254 \mathrm{~nm}$ ]. Combination of appropriate fractions and lyophilization afforded dinucleoside pentaphosphate in triethylammonium salt form. Passage of the solution of the triethylammonium salt in deionized $\mathrm{H}_{2} \mathrm{O}$ through a bed of Dowex $50 \mathrm{~W}-\mathrm{X} 8$ ion exchange resin $\left(\mathrm{Na}^{+}\right.$form) and lyophilization afforded $\mathbf{5}(15 \mathrm{mg}, 38 \%)$ as pentasodium salt. ${ }^{1} \mathrm{HNMR}\left(400 \mathrm{MHz}, \mathrm{D}_{2} \mathrm{O}\right): \delta 7.92(\mathrm{~d}, J=8.0 \mathrm{~Hz}, 2 \mathrm{H}), 5.95-5.92(\mathrm{~m}, 4 \mathrm{H}), 4.38-4.32$ $(\mathrm{m}, 4 \mathrm{H})$ 4.23-4.20 (m, 6H) ppm; ${ }^{13} \mathrm{C}$ NMR $\left(100 \mathrm{MHz}, \mathrm{D}_{2} \mathrm{O}\right): \delta 166.4,152.1,141.8$, $102.9,88.2,83.6(\mathrm{~d}, J=8.9 \mathrm{~Hz}), 73.8,69.8,65.1(\mathrm{~d}, J=5.2 \mathrm{~Hz}) \mathrm{ppm} ;{ }^{31} \mathrm{P}$ NMR $(162$ $\left.\mathrm{MHz}, \mathrm{D}_{2} \mathrm{O}\right): \delta-11.0(\mathrm{~m}, 2 \mathrm{P}),-22.4(\mathrm{~m}, 3 \mathrm{P}) \mathrm{ppm}$; IR (KBr): $v_{\max } 3870,3749,3690,3457$, 2923, 2741, 2332, 1605, 1481, 1388, 1336, 1306, 1247, 1117, 1079, 954, 825, 721, 649, $512 \mathrm{~cm}^{-1}$; LRMS (ESI-): $\mathrm{m} / z$ calcd for $\mathrm{C}_{18} \mathrm{H}_{27} \mathrm{~N}_{4} \mathrm{O}_{26} \mathrm{P}_{5}[\mathrm{M}-\mathrm{H}]^{-}$870.0; found 870.1.

\section{Results and Discussion}

As shown in Fig. 1, cytidine phosphoropiperidate (1) and uridine phosphoropiperidate (2) were treated with 0.4 equiv of cytidine tetraphosphate (3) and uridine tetraphosphate (4), respectively. In the presence of 2 equiv of DCI at $20^{\circ} \mathrm{C}$ in $N$-methylpyrrolidone, the reactions were stirred for 18-20 h. We found that dinucleoside pentaphosphate products were hardly separable from the closely related polyphosphate byproducts. Therefore, high performance liquid chromatography (HPLC) in addition to regular ion exchange chromatography was employed to afford the desired $\mathrm{Cp}_{5} \mathrm{C}(5)$ and $\mathrm{Up}_{5} \mathrm{U}(6)$ in $35-38 \%$ yields.

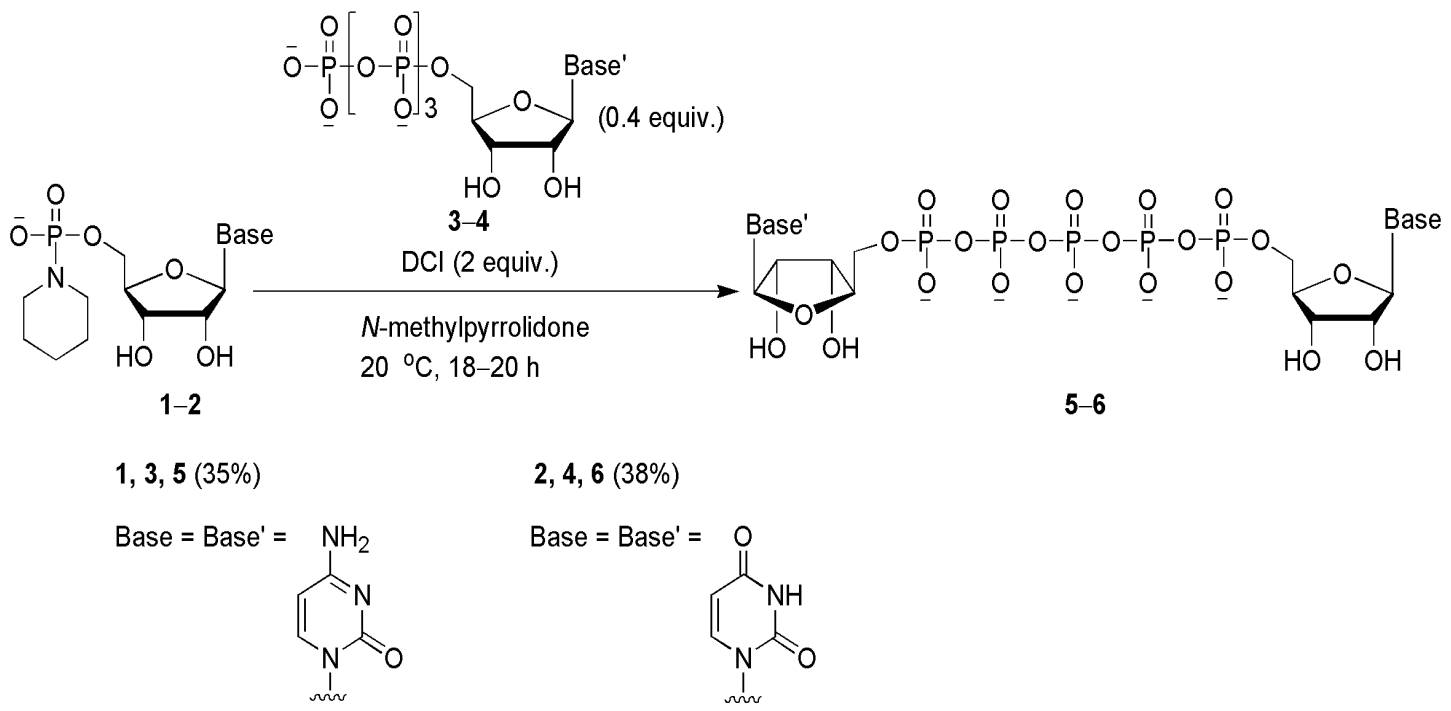

Figure 1. The $\mathrm{P}(\mathrm{V})-\mathrm{N}$ activation method for the synthesis of dinucleoside pentaphosphates (5-6).

\section{Summary}

In conclusion, the work reported in this paper presents an efficient protocol for the preparation of dinucleoside pentaphosphates. Compared to the previously reported synthetic methods, the $\mathrm{P}(\mathrm{V})-\mathrm{N}$ activation approach provided a facile and efficient approach for the synthesis of dinucleoside pentaphosphates.

\section{Acknowledgement}

The authors are grateful for the Masters' Innovative Foundation of Jiangxi science and technology normal university (YC2014-X04). 


\section{References}

[1] N. Stern, D. T. Major, H. E. Gottlieb, D. Weizman, B. Fischer, Org. \& Biomol. Chem. 8 (2009) 4637.

[2] C. H. V. Hoyle, R. H. Hilderman, J. J. Pintor, H. Schluter, B. F.King, Drug Dev. Res. 52 (2001) 260.

[3] V. Ralevic, J. Jankowski and H. Schluter, Br. J. Pharmacol. 134 (2001) 1073.

[4] A. G. Aranguez, A. Crooke, A. Peral, C. H. V. Hoyle, J. Pintor, Prog. Retinal Eye Res. 26 (2007) 674.

[5] J. G. Douglass, R. I. Patel, B. R. Yerxa, S. R. Shaver, P. S. Watson, K. Bednarski, R. Plourde, C. C. Redick, K. Brubaker, A. C. Jones, J. L. Boyer, J. Med. Chem. 51 (2008) 1007.

[6] K. A. Henzler-Wildman, V. Thai, M. Lei, M. Ott, M. Wolf-Watz, T. Fenn, E. Pozharski, M. A. Wilson, G. A. Petsko, M. Karplus, C. G. Hubner, D. Kern, Nature, 450 (2007) 838.

[7] E. Holler, B. Holmquist, B. L. Vallee, K. Taneja and P. Zamecnik, Biochemistry, 22 (1983) 4924.

[8] J. W. Pettegrew, D. W. Miles and H. Eyring, Proc. Natl. Acad. Sci. U. S. A. 74 (1977) 1785.

[9] J. G. Douglass, R. I. Patel, B. R. Yerxa, S. R. Shaver, P. S. Watson, K. Bednarski, R. Plourde, C. C. Redick, K. Brubaker, A. C. Jones, J. L. Boyer, J. Med. Chem. 51 (2008) 1007.

[10] J. Stepinski, M. Bretner, M. Jankowska, K. Felczak, R. Stolarski, Z. Wieczorek, A. L. Cai, R. E. Rhoads, A. Temeriusz, Nucleosides, Nucleotides Nucleic Acids, 14 (1995) 717.

[11] S. R. Shaver, J. L. Rideout, W. Pendergast, J. G. Douglass, E. G. Brown, J. L. Boyer, R. I. Patel, C. C. Redick, A. C. Jones, M. Picher, B. R. Yerxa, Purinergic Signalling 1 (2005) 183.

[12] W. Pendergast, B. R. Yerxa, J. G. Douglass, S. R. Shaver, R. W. Dougherty, C. C. Redick, I. F. Sims, J. L. Rideout, Bioorg. Med. Chem. Lett. 11 (2001) 157.

[13] J. F. Scott, P. C. Zamecnik, Proc. Natl. Acad. Sci. U. S. A. 64 (1969) 1308.

[14] W. Pendergast, B.R. Yerxa, J.G. Douglass, et al., Synthesis and P2Y receptor activity of a series of uridine dinucleoside 5'-polyphosphates, Bioorg. Med. Chem. Lett. 11 (2001) 157.

[15] L.C. Davies, J.A. Stock, S.E. Barrie, et al., Dinucleotide analogues as inhibitors of thymidine kinase, thymidylate kinase, and ribonucleotide reductase, J. Med. Chem. 31 (1988) 1305.

[16] P. Feldhau, T. Frohlich, R. S. Goody, Eur. J. Biochem. 57 (1975) 197.

[17] Q. Sun, S.-S. Gong, J. Sun, C.-J. Wang, S. Liu, G.-D. Liu, C. Ma, Tetrahedron Lett. 55 (2014) 2114. 